\title{
HIGH PREVALENCE OF HEPATITIS B VIRUS AMONG FEMALE SEX WORKERS IN NIGERIA
}

\author{
J.C. FORBI, N. ONYEMAUWA, S.D. GYAR, A.O. OYELEYE, P. ENTONU \& S.M. AGWALE
}

\begin{abstract}
SUMMARY
Hepatitis B virus (HBV) infection is endemic in Nigeria and constitutes a public health menace. The prevalence of HBV infection in many professional groups has been described in Nigeria. However, literature on HBV infection among female sex workers (FSW) in Nigeria is scanty. FSW in Nigeria are not subjected to a preventive control of HBV infection. This study assesses the extent of spread of HBV among FSW in Nigeria. Seven hundred and twenty $(n=720)$ FSW (mean age $=26.7$ years) were tested for hepatitis B surface antigen (HBsAg) by a double antibody sandwich ELISA method. The overall HBV prevalence among the FSW was $17.1 \%$. FSWs between the ages of 31-35 year (20.5\%) and those with 'age-at-first-sex' below 10 years of age $(28 \%)$ were most affected. This high prevalence of a vaccine preventable disease is unacceptable, therefore, vaccination of this high risk HBV reservoir group should be considered worthwhile.
\end{abstract}

KEYWORDS: HbsAg; Prevalence; Female sex workers.

\section{INTRODUCTION}

Despite the availability of a safe and effective vaccine against hepatitis B infection for over two decades now, the overall burden of the disease remains enormous with over two billion people infected worldwide and approximately one million deaths occur annually from HBV related illness ${ }^{11}$. Several studies have demonstrated that HBV is endemic in Nigeria and have also shown the seroprevalence among various groups ${ }^{2,4,6,13,14}$. Data on the extent of spread of the virus among commercial sex workers in Nigeria is highly limited. A single study among sex workers from southern Nigeria was hospital based and therefore had a selection bias because sampling was done in the clinic ${ }^{7}$. Sexual transmission of HBV infection has been confirmed in several studies $^{7,8,12}$. This study describes the prevalence of HBV infection in a population of female sex workers (FSW) in north-central Nigeria who by their profession (multiple sex partners) are at increased risk of acquiring and transmitting the disease. We also investigated the role of 'age-at-first-sex' as a factor for HBV infection in this population.

\section{METHODOLOGY}

Study population and sample collection: In 2006/2007, we contacted persons who solicit clients for sexual activity in areas known to be frequented by prostitutes in Nasarawa State of Nigeria. Nasarawa State is located $50 \mathrm{~km}$ East of Abuja Federal Capital territory. A total of 720 prostitutes were recruited for the study. These prostitutes (all females) were full-time prostitutes working in brothels and receive money for sex. Inclusion criteria for the study population were voluntary participation, age above sixteen years and individuals must be females. The sex, age and age-at-first-sex were taken from each prostitute voluntarily. After obtaining written informed concern from each prostitute, $5-10 \mathrm{~mL}$ venous blood samples were taken and the plasma stored at $-24{ }^{\circ} \mathrm{C}$ at the Virology laboratory of Innovative Biotech until tested for evidence of $\mathrm{HBV}$ infection.

HBV testing: The Shantest ${ }^{\mathrm{TM}}$ - HBsAg ELISA (SHANTHA BIOTECH LIMITED - India, Lot number: DHB 01 306) was used for the detection of HBsAg in plasma. Briefly, the Shantest ${ }^{\mathrm{TM}}-\mathrm{HBsAg}$ ELISA (analytical sensitivity: $0.2 \mathrm{ng} / \mathrm{mL}$; assay sensitivity: $99.9 \%$; specificity: $100 \%$ ) is based on the double antibody sandwich method and detects HBsAg in plasma which is a marker of active HBV infection. The test was conducted following manufacturers instructions and the microplates read at a wavelength of $450 \mathrm{~nm}$ using the ELISA reader (BIO-RAD 2100, version 6.1, USA). The presence or absence of HBsAg was determined by relating the absorbance of the unknown sample to the cut-off value. The cut-off value is the mean of the optical density (OD) of the negative control plus the factor 0.025. Specimens with OD values greater than or equal to the cut-off value established with the negative control were considered positive while those with ODs lower than the cut-off value were recorded as negative.

All analysis was done after recording the date on a Microsoft Excel worksheet on a Windows ' 98 platform. Proportions were calculated using the chi-square test at $95 \%$ confidence level. 


\section{RESULTS}

Of the seven hundred and twenty $(n=720)$ FSW who agreed to participate in the study, HBsAg was present in one hundred and twenty three $(n=123)$ giving an overall prevalence of $17.1 \%$. The FSW were between the ages of 16 and 50 years (mean age $=26.7$ years). All participants in the study were females soliciting sex for money. Table 1 and Fig. 1 show the prevalence of HBsAg according to age groups and age-at-first-sex respectively among the FSW in Nigeria. The number tested and those positive in the age group at first sex were as follows: < 10 years $(7 / 25), 11-14$ years $(24 / 143), 15-18$ years $(76 / 433)$, $19-22$ years $(14 / 103),>23$ years $(2 / 16)$.

Table 1

Distribution of HBsAg marker according to age group among FSW in Nigeria

\begin{tabular}{llll}
\hline $\begin{array}{l}\text { Age groups } \\
\text { (years) }\end{array}$ & $\begin{array}{l}\text { Number } \\
\text { tested (NT) }\end{array}$ & $\begin{array}{l}\text { Number } \\
\text { positive (NP) }\end{array}$ & $\begin{array}{l}\text { Percentage } \\
\text { Positive }(\%)\end{array}$ \\
\hline $16-20$ & 147 & 26 & 17.7 \\
$21-25$ & 247 & 41 & 16.7 \\
$26-30$ & 164 & 26 & 15.9 \\
$31-35$ & 78 & 16 & 20.5 \\
$>36$ & 85 & 14 & 16.5 \\
\hline Total & 720 & 123 & \\
\hline
\end{tabular}

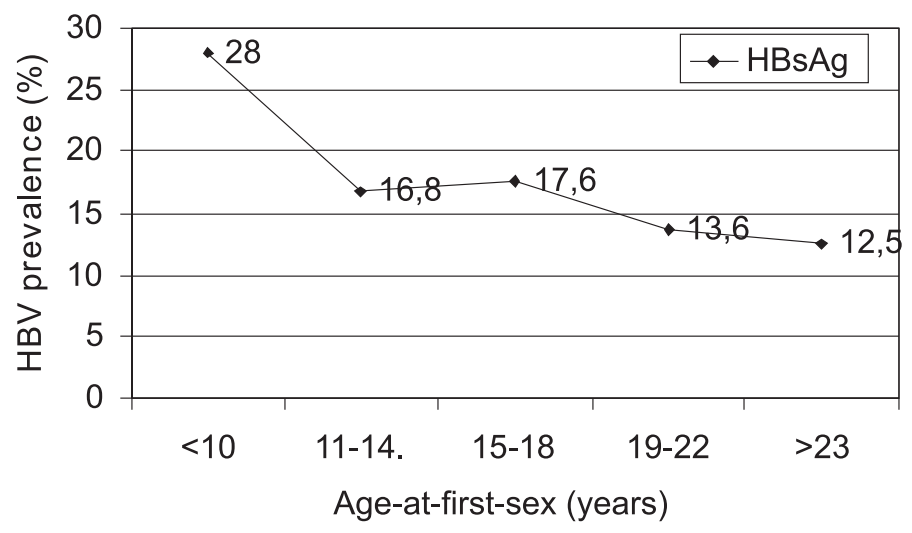

Fig. 1 - Relationship between HBsAg infection and age-at-first-sex in Nigeria.

\section{DISCUSSION}

Nigeria has been classified as an HBV endemic zone ${ }^{6}$. Although this classification gives a fair picture of the global HBV endemicity, it fails to take into account the variability of the disease within various professional groups ${ }^{1,6,13}$. Also, most of information of HBV prevalence in Nigeria is available from blood donors ${ }^{5,15}$. In this study, the prevalence of HBsAg marker (indicating HBV infection) among female sex workers in Nasarawa State of Nigeria was $17.1 \%$. This prevalence is higher $(p<0.05)$ than in many other professional groups studied in Nigeria. This is critical owning to the fact that this group has a greater probability of transmitting and maintaining the virus in the community because of their frequent and many sexual partners. A recent limited descriptive study among prostitutes in a clinic in Benin City of Nigeria showed that $14.1 \%$ of the prostitutes were $\mathrm{HBV}$ infected ${ }^{7}$. This high HBV prevalence among sex workers in Nigeria is an indication that active sexual transmission is an important factor in the spread of HBV in this nation and that sex workers are a reservoir group for the maintenance and transmission of the virus. This high prevalence is unacceptable for a disease that has an effective vaccine that has been demonstrated to be capable of interrupting the transmission of HBV infection ${ }^{3}$. Although our group strongly supports the WHO recommendation for universal vaccination against $\mathrm{HBV}$ as the best strategy for reducing the risk of $\mathrm{HBV}$ infection ${ }^{18,19}$, this has not been feasible in Nigeria. We therefore quickly call for innovative programs incorporating wide spread HBV education and vaccination among sex workers in Nigeria to achieve immediate benefit within the targeted high risk population as an immediate first step to the global fight against HBV infection.

The prevalence of HBV according to age groups among the FSW was highest in individuals in the 31-35 years age group although not statistically significant $(p>0.05)$. This is in consonance with VÁZQUEZ-MARTÍNEZ et al. ${ }^{17}$ who recognized that being above 30 years of age is a risk factor for $\mathrm{HBV}$ infection. The increased predisposition of HBV with increased age could be attributable to the duration of prostitution. In our study, only individuals above 16- years were recruited. Health workers will need to continue verification of vaccination status and offer vaccination to adults when they come to the clinics for their medical needs.

Injecting drug use and anal sex have been documented as risk factors for $\mathrm{HBV}$ infection in $\mathrm{FSWs}^{10,16}$. We disclose here that the prevalence of HBV was highest among Nigerian FSWs with 'age-at-first-sex' below 10 years $(28 \%, p<0.05)$. This correlates with studies from Mexico that early age of sexual activity increases the risk of HBV infection ${ }^{17}$. Furthermore, researches from North America and South Africa have shown that women who have experienced child sexual abuse are more likely to engage in risky sex ${ }^{9,20}$. The integration and strengthening of HBV vaccination in the already existing childhood vaccination structure in Nigeria is a proactive approach to protect children from potential HBV-related complications in later life before they undertake high risk behaviours. It is worth noting that $86.9 \%$ (107/123) HBV positive FSW in this study had sexual involvement before 18 years of age.

Our findings are useful in planning public health programs for the control of HBV in Nigeria and add to the information demonstrating the endemicity of HBV in Africa's most populous nation. We call for innovative and immediate implementation of a general child and adolescent (catch-up) immunization against HBV to prevent the further spread of this virus.

\section{RESUMO}

\section{Alta prevalência de hepatite pelo vírus B entre trabalhadoras do sexo feminino na Nigéria}

A hepatite pelo vírus B (HBV) é infecção endêmica na Nigéria e constitui problema de saúde pública. A prevalência da infecção HBV em muitos grupos profissionais foi descrito na Nigéria. No entanto, a 

trop. S. Paulo, 50(4): 219-221, 2008.

literatura da infecção HBV entre trabalhadoras do sexo feminino (FSW) na Nigéria é escasso. FSW na Nigéria não são submetidas a um controle preventivo de infecção de HBV. Este estudo avalia a extensão da disseminação de HBV entre FSW na Nigéria. Setecentos e vinte $(\mathrm{n}=$ 720) FSW (média de idade $=26,7$ anos) foram testadas para antígeno de superfície da hepatite B (HBsAg) pelo método ELISA usando sandwich de duplos anticorpos. A prevalência total de HBV entre o FSW foi $17,1 \%$. FSWs entre as idades de 31-35 anos (20,5\%) e abaixo de 10 anos de idade (28\%) foram mais afetadas. Esta alta prevalência de doença evitável pela vacinação é inaceitável, portanto, vacinação deste grupo de alto risco de HBV deve ser considerada fundamental.

\section{REFERENCES}

1. AKANI, C.I.; OJULE, A.C.; OPURUM, H.C. \& EJILEMELE, A.A. - Sero-prevalence of hepatitis B surface antigen $(\mathrm{HBsAg})$ in pregnant women in Port Harcourt, Nigeria. Niger. Postgrad. Med. J., 12(4): 266-70, 2005.

2. BELO, A.C. - Prevalence of hepatitis B virus markers in surgeons in Lagos, Nigeria. East Afr. med. J., 77: 283-285, 2000.

3. BONANNI, P.; PESAVENTO, G.; BECHINI, A. et al. - Impact of universal vaccination programmes on the epidemiology of hepatitis B: 10 years of experience in Italy. Vaccine, 21: 685-691, 2003.

4. COBELENS, F.G.; VAN SCHOTHORST, H.J.; WERTHEIM-VAN DILLEN, P.M. et al. - Epidemiology of hepatitis B infection among expatriates in Nigeria. Clin. infect. Dis., 38: 370-376, 2004.

5. EJELE, O.A. \& OJULE, A.C. - The prevalence of hepatitis B surface antigen (HBsAg) among prospective blood donors and patients in Port Harcourt, Nigeria. Niger. J. Med., 13: 336-338, 2004.

6. FORBI, J.C.; GABADI, S.; ALABI, R. et al. - The role of the triple infection with hepatitis $B$ virus, hepatitis $C$ virus, and human immunodeficiency virus (HIV) type- 1 on CD4 ${ }^{+}$ lymphocyte levels in the highly HIV infected population of North-Central Nigeria. Mem. Inst. Oswaldo Cruz, 102: 535-537, 2007.

7. HALIM, N.K.D.; KUBENYINJE, E.P. \& ONUNU, A. - Sero-prevalence of hepatitis B surface antigen (HBsAg) in sexually transmitted disease patients. J. Coll. Med., 9: 107-109, 2004.

8. INABA, I.; OHKAWA, R.; MATSUURA, A.; KUDOH, J. \& TAKAMIZAWA, H. - Sexual transmission of hepatitis B surface antigen. Infection of husbands by HbsAg carrierstate wives. Brit. J. ven. Dis., 55: 366-368, 1979.
9. KALICHMAN, S.C. \& SIMBAYI, L.C. - Sexual assault history and risks for sexually transmitted infections among women in an African township in Cape Town, South Africa. AIDS care, 16: 681-689, 2004.

10. LANGE, W.R.; CONE, E.J. \& SNYDER, F.R. - The association of hepatitis delta virus and hepatitis B virus in parental drug abusers, 1971 to 1972 and 1986 to 1987. Arch. intern. Med., 150: 365-368, 1990.

11. LAVANCHY, D. - Hepatitis B virus epidemiology, disease burden, treatment and current and emerging prevention and control measures. J. viral Hepat., 11: 97-107, 2004

12. LOK, A.S.F.; CONJEEVARAM, H.S. \& NEGRO, F. - Hepatitis B and D. In: SCHIFF, E.R.; SORREL, M.F. \& MADDREY, W.C., ed. Schiff's diseases of the liver. 10. ed. Philadelphia, Lippincott Williams \& Wilkins, 2007. p. 739-806.

13. ODEMUYIWA, S.O.; OYEDELE, O.I.; FORBI, J.C, et al. - Hepatitis B surface antigen (HbsAg) in the sera of medical, nursing and microbiology students in Ibadan, Nigeria. Afr. J. Med. med. Sci., 30: 333-335, 2001.

14. OLUBUYIDE, I.O.; OLA, S.O.; ALIYU, B. et al. - Prevalence and epidemiological characteristics of hepatitis $\mathrm{B}$ and $\mathrm{C}$ infections among doctors and dentists in Nigeria. East Afr. Med. J., 74: 357-361, 1997.

15. OTEGBAYO, J.A.; FASOLA, F.A. \& ABJA, A. - Prevalence of hepatitis B surface and e antigens, risk factors for viral acquisition and serum transaminase among blood donors in Ibadan, Nigeria. Trop. Gastroent., 24: 196-197, 2003.

16. ROSENBLUM, L.; DARROW, W.; WITTE, J. et al. - Sexual practices in the transmission of hepatitis B virus and prevalence of hepatitis delta virus infection in female prostitutes in the United States. J. Amer. med. Ass., 267: 2477-2481, 1992.

17. VÁZQUEZ-MARTÍNEZ, J.L.; COREÑO-JUÁREZ, M.O.; MONTAÑO-ESTRADA, L.F.; ATTLAN, M. \& GÓMEZ-DANTÉS, H. - Seroprevalence of hepatitis B in pregnant women in Mexico. Salud publ. Méx., 45: 165-170, 2003.

18. WHO - Hepatitis B vaccine. Wkly epidemiol. Rec., 79: 255-263, 2004.

19. WHO - The children's vaccine initiative and the global programme for vaccines and immunization: recommendations from the Special Advisory Group of Experts. Part 1. Wkly epidemiol. Rec., 71: 261-266, 1996.

20. WINGOOD, G.M. \& DICLEMENTE, R.J. - Child sexual abuse, HIV sexual risk and gender relations of African-American women. Amer. J. prev. Med., 13: 380-384, 1997.

Received: 15 January 2008

Accepted: 8 April 2008 